ELORE (ISSN 1456-3010), vol. 20 - 1/2013.

Julkaisija: Suomen Kansantietouden Tutkijain Seura ry.

[http://www.elore.fi/arkisto/1_13/haapoja.pdf]

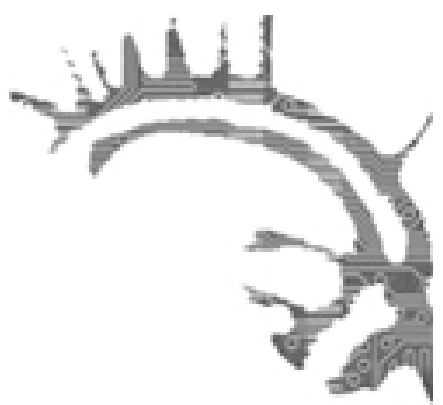

\title{
KIRJA-ARVIO
}

\section{VALTAISIA HUUTOJA}

KOIVUNEN, ANU, LEHTONEN, MIKKO (toim.) 2011: Kuinka meitä kutsutaan. Kulttuuriset merkityskamppailut nyky-Suomessa. Tampere: Vastapaino. 299 sivua.

\section{Heidi Haapoja}

Media-, taiteen- ja sukupuolentutkimuksen alan tutkijoiden yhteistyönä syntynyt Kuinka meitä kutsutaan -artikkelikokoelma avaa näkökulmia viimeisen kymmenen vuoden aikana Suomessa tapahtuneisiin poliittisiin, kulttuurisiin ja ideologisiin ilmiöihin. Tekijöiden mukaan "tarkastellut nykykulttuurin ilmiöt ovat kuin peilin sirpaleita, joissa nyky-yhteiskunta eri muodoissa esittää itsensä, uusintaa ja muokkaa itseään sekä kamppailee sisällöstään” (s. 30). Artikkelien analyysien kohteina ovat muun muassa Tuntemattoman sotilaan näytelmäversion vastaanotto, suomalaisen television historiaa talouden näkökulmasta luotaava diskurssi, improvisaatioteatteri ja uusi kapitalismi, Big Brother -tosi-tv-ohjelman valtasuhteet, suomalaisuuden representaatiot monikulttuurisessa tv-sarjassa sekä poliitikot julkkishahmoina.

Artikkelikokoelma tarttuu aiheeseen kamppailun ja valtasubteiden näkökulmasta: uuskapitalistisessa Suomessa kulttuurisia merkityksiä luovat ja yhteiskunnan jäsenille suunnattuja kutsuhuutoja tuottavat erilaiset, välillä hyvinkin pirstaloituneet tahot. Tässä kutsuhuutojen viidakossa nykykansalainen voi tarttua esimerkiksi uusliberaalien globaalistajien, hyvinvointivaltion perinnön puolustajien tai uusnationalistien vaihtoehtoihin. Nämä diskurssit pyrkivät kiivaasti tuomaan julkiseen puheeseen oman näkemyksensä suomalaisuudesta ja Suomesta sekä tuottamaan näille ajatuksille merkityksiä. Selvää 
on, että tällä hetkellä uusliberaalien globaalistajien ääni on vahvin, vaikka vastalauseita kuuluukin usealta suunnalta.

Valtaa luodataan artikkeleissa kulttuurin käsitteen kautta. Kirjan taustalla olevan tutkimusprojektin lähtökohtana on, että vallan rakentumisessa kulttuurilla on merkittävä rooli Suomen kaltaisessa myöhäismodernissa yhteiskunnassa. Valtatutkimuksessa kulttuuri nähtiin pitkään merkityksettömänä asiana, ja kulttuuri miellettiin yhteisen inhimillisyyden sekä henkisyyden kuvaksi. Valtaa koskevassa puheessa käsiteltiin sellaisia vallankäytön muotoja kuten pakottava väkivalta, tukahduttava pakkovalta, käskevä autoritaarinen valta sekä velvoittava institutionaalinen valta. Nykytutkimuksessa on alettu korostaa, että "vallan toimintaa ei voi ymmärtää, ellei kulttuuria oteta huomioon, ja että kulttuuria ei voi ymmärtää, ellei sen tutkimuksessa oteta vakavasti valtaan liittyviä ulottuvuuksia" (s. 17). Kulttuurin ajatellaan olevan ihmisten tapa elää ja se muodostuu heidän arkisia toimiaan ohjaavista käsityksistä. Tästä lähtökohdasta käsin artikkelin kirjoittajat luotaavat seuraavia kysymyksiä: Missä ja kenellä valta on? Kuka sitä luo ja miten? Miltä yksilöstä tuntuu näiden kulttuuristen valtakamppailuiden keskellä? Miten julkisissa puhutteluissa luodaan ja merkitään meisyys? Keitä ovat "he"?

\section{KULTTUURISEN PUHEEN RAILAKKAITA ÄÄNIÄ}

Artikkelikokoelman ote on pitävä läpi kirjan. Keskityn erittelemään lyhyesti tässä arviossa kolmea erityisesti folkloristiikan näkökulmasta kiinnostavaa artikkelia: analyyttisesti ja syväluotaavasti erilaisia kulttuurisia merkityksiä ja kamppailuja artikkelikokoelmassa lähestyvät erityisesti Jussi Ojajärvi, Leena-Maija Rossi ja Mikko Hautakangas. Ojajärven artikkeli "Yhteiskunnallisen kamppailun näyttämöt. Linnan-Smedsin Tuntematon sotilas ja vastaanotto" luotaa seikkaperäisesti Kansallisteatterin näytelmän ympärillä vellonutta keskustelua, johon liittyi monitahoisia ja moneen suuntaan ulottuvia diskursiivisia positioita. Artikkelin otsikko on hienolla tavalla monitasoinen, sillä sekä yhteiskunta, kamppailu että näyttämö saavat artikkelissa ylleen monia merkityksiä. Ojajärvi on löytänyt lehtiartikkeleista, tv-ohjelmien puheesta ja internetin keskustelupalstojen tekstimassasta erilaisia tulkintamalleja (mm. sensaatio-, nationalistinen, huoli-, pasifistinen ja nyky-yhteiskunnallinen malli), joiden mukaan hän on ryhmittänyt näytelmään liittynyttä keskustelua.

Ojajärven tarkka katse on onnistunut tuomaan esille varsin kirjavan joukon kulttuurisia kutsuhuutoja, joita hän tarkastelee kylmäpäisesti, tosin välillä melko kärkkäästi ja hieman näytelmän tekijäjoukkoa puolustelevasti. Kuitenkin: harvemmin tieteellistä artikkelia lukiessa liikuttuu ja eläytyy lukukokemukseen voimakkaasti tunteen kautta, mutta Ojajärven tyyli, värikäs kerronta ja tulkintamallien välille syntyvä keskustelu saavat ainakin allekirjoittaneen kurkkuun nousemaan palan tunteen. Tämä merkinnee myös sitä, että Ojajärvi on tarttunut aiheeseen, joka on yhteiskunnallisesti merkittävä, identiteettiä muovaava ja rakentava sekä monelle nyky-yhteiskunnan jäsenelle henkilökohtainen, perustavanlaatuisia arvoseikkoja koskettava. Kansallisteatterin Tuntematon todellakin onnistui esittämään niin voimakkaita kutsuhuutoja, että se sai kulttuuriset kamppailut leimahtamaan valtaisiin liekkeihin. 
Sukupuolentutkija Leena-Maija Rossi on ottanut artikkelissaan "Vieraus ja tuttuus liikkeessä - kunnialliset ja vääränlaiset suomalaiset Mogadishu Avenuella" analyyttisen katseensa kohteeksi Jari Tervon käsikirjoittaman tv-sarjan. Maahanmuuttajalähiötä kuvannut fiktiivinen sarja esitettiin MTV3-kanavalla vuonna 2006, jolloin niin sanottu maahanmuuttokriittinen keskustelu ei ollut vielä noussut valtapuheen keskiöön. Rossi tulkitsee sarjaa mielenkiintoisesti ajallisessa kontekstissaan, mutta huomioi myös viimeaikaisten muuttuneiden yhteiskunnallisten diskurssien suunnat. Rossi tarkastelee analyysissaan, miten suomalaisuutta tv-sarjassa representoidaan ja pohtii erityisesti valkoisuuden, sukupuolen ja seksuaalisuuden ruumiillisten esitysten merkkimuodostelmia. Vaikka tv-sarja ei ehkä ole folkloristeille ominta analyysimaastoa, ovat etnisyyden ja Suomi-klišee-kuvien tarkastelut perinteentutkijalle varsin hersyviä ja ajatuksia herättäviä.

Mikko Hautakangas valottaa artikkelissaan "Käytä valtaasi! Aktivoidut yleisöt ja toimijuuden rajat Suomen Big Brotherissa" digitaalisen aikakauden mediatekstejä, tosi-tv:tä ja sen osallistujuuden aspekteja. Tosi-tv-ilmiössä toimijuuden ja tekijyyden asetelmat poikkeavat totutusta kaavasta, minkä mahdollistavat digitaaliset viestintävälineet sosiaalisine medioineen. Hautakangas luotaa Big Brother-tv-ohjelmaan liittynyttä puhetta haastattelu- ja internetin keskustelupalsta-aineistojen avulla ja esittää, että kansalaisten osallistuminen tv-ohjelman sisältöön esimerkiksi internetissä keskustelemalla ja kommentoimalla luo eräänlaisen "meidän ja median" välisen aktiivisen tilan. Media koetaan eräänlaiseksi poliittisten vallanpitäjien kaltaiseksi "herraksi", jota voidaan internetyhteisöissä kyseenalaistaa, ja näin kokea osallistumisen ja hallinnan tunteita, vaikka samalla kuitenkin käytännössä toimitaan vallitsevan mediakulttuurin rajoissa. Mielenkiintoista Hautakankaan artikkelissa on "tavallisen ihmisen" äänen tavoittaminen aineiston kautta ja sen keskustelu valtarakenteiden kanssa; vastaavanlaisia asetelmia on nähtävissä historiassakin, mutta näin selkeitä ja kuuluvia aineistoja tuskin aiemmin on ollut mahdollista saada.

Kaiken kaikkiaan artikkelit puhuvat sen seikan puolesta, että valta muodostuu kulttuurissa, erilaisissa julkisissa puhutteluissa ja siinä, miten niihin reagoidaan. Suomen kaltaisessa yhteiskunnassa kansalaisilla on valtaa, ainakin tiettyjen säännöstöjen puitteissa.

\section{NYKYKULTTUURIN TULKIT}

Käsillä oleva artikkelikokoelma luo katseensa juuri siihen aiheeseen, jonka asiantuntemusta folkloristeilta usein penätään, nykykulttuuriin. Miten käsite sitten halutaankaan määritellä, voidaan ainakin tämän artikkelikokoelman tutkijoiden sanoa tarttuneen todella päivänpolttaviin ja kansalaisten syviä rivejä luotaaviin aiheisiin. Käsillä olevat aihelmat voisivat ainakin suurelta osalta olla yhtä lailla folkloristien tulkitsemia, ja kenties niihin voisi saada oppialan perspektiivien kautta myös erilaista syvyyttä. Kun puhutaan nykyisyydestä, on läsnä aina myös menneisyys, ja tämän suhteen erittely olisi kiinnostavaa tämäntyyppisten aiheiden yhteydessä. Mediatutkijoiden polttopiste on selvästi kiinni tässä hetkessä, mutta äärimmäisen mielenkiintoista olisi tarkastella vaikkapa kansalaisten internetosallistumista suhteessa aiempiin vallan ja kansalaisten välillä 
käytyihin diskursseihin. Tai esimerkiksi suomalaisuus-puheen rakentumista tänä päivänä kansallisromantiikan perspektiivistä!

Palatakseni vielä artikkelikokoelman tunnelmaan, totean vain, että Kuinka meitä kutsutaan? -kirjan tutkijat ovat tyylissään melko uskaltavia. Nämä kirjoittajat eivät pidä kynttilää vakkansa alla, eivätkä jää hienotunteisesti sivuun odottelemaan. Osassa artikkeleita sävy on jopa hiukan kiukkuisen räyheä ja maailmaaparantava. Ajan ilmiöt vyöryvät silmille tunteen palolla, mutta lukija antaa ylevien objektiivisuus-vaateiden jäädä ajatusten reunoille. Tällaista kieltä on nautinnollista ja koukuttavaa lukea, se on selvä. Ja ehkä kulttuurisiin kutsuhuutoihin on vastattava huudahduksilla, jotta tutkimus ylipäänsä saa vastakaikua yhteiskunnasta?

Filosofian maisteri, musiikin kandidaatti Heidi Haapoja tekee väitöskirjaa Helsingin yliopiston folkloristiikan oppiaineessa kalevalamittaiseen nykyrunolauluun liittyvästä puheesta. 